\title{
PENGELOLAAN PERKULIAHAN MATA KULIAH KEWIRAUSAHAAN DALAM MENINGKATKAN MINAT BERWIRAUSAHA MAHASISWA EBIS INSTITUT AGAMA ISLAM NEGERI MADURA
}

\author{
Dwi Anisa dan Saiful Hadi \\ Institut Agama Islam Negeri Madura \\ Email:adwi7591@gmail.com dan saiful.hadi66@gmail.com
}

\begin{abstract}
Abstrak
Minat wirausaha setiap individu muncul bersamaan dengan upaya seseorang untuk memperoleh pemahaman tentang wirausaha yang diperoleh melalui aktifitas keseharian melakukan usaha mandiri di lingkungan sekitar, melalui pengetahuan dari kuliah baik aspek teori kewirausahaan dan praktek kewirausahan sebagai tuntutan akademik sehingga berdampak pada tumbuhnya motivasi berwirausaha. Penelitian ini dilakukan secara kualitatif yaitu menelusuri aktifitas perkuliahan mahasiswa program studi di lingkungan Fakultas Ekonomi Bisnis IAIN Madura. Hasil penelitian menunjukkan bahwa; pertama, merancang perkuliahan dengan sebaik mungkin yang mengacu pada silabus, menyiapkan referensi dan teori, mahasiswa didorong untuk ikut aktif dalam kelas. Kedua, pelaksanaan mata kuliah kewirausahan yaitu adanya kegiatan diskusi dan praktik lapangan. Saat diskusi mahasiswa dibekali pengetahuan tentang tentang kewirausahaan, bisnis, yang kemudian dikuatkan dengan diadakannya praktik usaha di luar kelas. Ketiga, tingkat keberhasilan program perkuliahan mata kuliah kewirausahaan adalah munculnya ide kreatif dan inovatif mahasiswa untuk melakukan kegiatan wirausaha kecil di lingkungan kampus seperti menjual kue makanan kepada mahasiswa lain sebagai wujud minat berwirausaha.
\end{abstract}

Kata Kunci: Mata Kuliah Kewirausahaan, Minat Berwirausaha

\begin{abstract}
Entrepreneurial interest of each individual arises along with one's efforts to gain an understanding of entrepreneurship obtained through daily activities of doing business independently in the surrounding environment, through knowledge from lectures both aspects of entrepreneurial theory and entrepreneurial practice as academic demands so that it impacts on the growth of entrepreneurial motivation. This research was conducted qualitatively by tracing the lecture activities of study program students at the Faculty of Business Economics IAIN Madura. The results showed that; first, designing lectures as well as possible that refers to the syllabus, preparing references and theories, students are encouraged to take an active part in class. Second, the implementation of entrepreneurship courses, namely the existence of discussion activities and field practice. During the discussion the students were equipped with knowledge about entrepreneurship, business, which was then strengthened by holding business practices outside the classroom. Third, the level of success of the entrepreneurship course courses is the emergence of creative and innovative ideas for students to carry out small entrepreneurial activities on campus such as selling food cakes to other students as a form of entrepreneurial interest.
\end{abstract}

Keyword: Entrepreneurship Course, Entrepreneurial Interest 


\section{PENDAHULUAN}

Kewirausahaan adalah isu perbincangan yang sangat mearik, karena berhubungan dengan aspek sosial ekonomi masyarakat atau bangsa, Kegiatan kwirausahaan yang dilakukan oleh masyarakat dan ditpang oleh regulasi dari pemerintah dapat membuka lapangan kerja sektor informal/UMKM, menumbuhkan tingkat kompetitif suatu bangsa, dan meningkatkan perolehan kesejahteraan masyarakat dan kemajuan suatu negara. ${ }^{1}$

Kewirausahan sangat berhubungan dengan aspek ekonomi, karena aktifitas yang dipilih adalah kegiatan yang menuntut skill atau ketarampilan mengelola unit usaha yang dapat menghasilkan pendapatan, sangat tepat jika pemerintah mengeluarkan Instruksi Presiden R.I Nomor 4, tahun 1995 tentang "gerakan nasional memasyarakatkan dan membudayakan kewirausahaan". Instruksi tersebut ditindak lanjuti oleh setiap kementerian, khususnya Departemen Pendidikan Nasional dengan mengembangkan kewirausahaan dalam format paket pendidikan dan aktifitas usaha bagi siswa SMK dan mahasiswa. ${ }^{2}$ Menciptakan lapangan pekerjaan melalui aktifitas kewirausahaan merupakan solusi mengatasi pengangguran, pola aktifitas seperti ini hakekatnya adalah wujud erubahan pola pikir yaitu bergantung "mencari pekerjaan" berubah "memperluas lapangan kerja baru" khususnya komunitas mahasiswa.

Gagasan tentang kewirausahaan yang di dalamnya terdapat dimensi pendidikan, bahwa bangsa Indonesia memberikan perhatian secara serius dan menggalakannya pada tahun 1980-an, namun tidak dapat berkembang dengan baik disebabkan karena selalu kalah bersaing dengan kelompok pengusaha besar yang sering kali memberangus hadirnya pengusaha atau wirausahaan baru yan skalanya tidak besar dengan kata lain sering mati suri, baru memasuki era tahun 2000-an, penataan kewirausahaan dilekatkan upaya pmbinaan dan pengembangannya melalui pendidikan. Sebagaimana dalam sejarahnya Dirjend. Dikti Departemen Pendidikan Nasional meluncurkan program Hibah Pendanaan kepada mahasiswa dalam kegiatan kewirausahaan, .... 4

Pendidikan tinggi sebagai tempat pembinan dan pengembangan mahasiswa terhadap mental dan skill kewirausahaan, sehingga setelah lulus dari kegiatan pendidikan mereka memiliki pengalaman melakukan aktifitas wirausaha, seperti halnya di negara negara maju yaitu Amerika, Eropa, Negaraa tetangga Jepang dan Malasyia, serta Singapura, memberikan pengalaman dalam perkuliahan disisipkan materi entrepreneuship. Sedangkan di Indonesia mengawali pendidikan kewirausahaan menjadi rumpun matakuliah kelompok berkarya (MKB). ${ }^{5}$ Pendidikan kewirausahaan yang dimasukkan dalam matakuliah diimplementasikan dalam kurikulum pendidikan yang dirancang dengan bobot SKS sekitar 2-3 SKS. ${ }^{6}$

1 Zuhrina Aidha, "Pengaruh motivasi Terhadap Minat Berwirausaha Mahasiswa Fakultas Kesehatan Masyarakat Universitas Islam Negeri Sumatera Utara,” Jurnal Jumantik 1, no. 1 (2016): 42.

2 Nova Tiara Ramdhani dan Ida Nurnida, "Pengaruh Mata Kuliah Kewirausahaan Terhadap Minat berwiarausaha Mahasiswa,” Jurnal Ecodomica 1, no. 1 (2017): 90.

Ramdhani dan Nurnida, 90.

4 Ahmad Subagyo, Eko Wahyu Widayat, dan Syahruddin, Kewirausahaan (Jakarta: Mitra Wacana Media, 2018), 3.

5 Ahmad Subagyo, Eko Wahyu Widayat dan Syahruddin, Kewirausahaan, (Jakarta: Mitra Wacana Media, 2018) hlm. 3

6 I Wayan Widnyana, Sapta Rini Widyawati, dan G. Oka Warmana, "Pengaruh Pemberian Mata Kuliah Kewirausahaan dan Pelatihan Wirausaha Terhadap Minat Wirausaha Ekonomi Kreatif," Jurnal Bakti Masyarakat Indonesia 1, no. 1 (2018): 172. 
Mengenalkan materi kewirausahaan entrepreneurship dalam pembelajaran khususnya di lingkungan Pendidikan Tinggi Keagamaan Islam (PTKIN), dilakukan melalui tatap muka di kelas antara dosen bersama mahasiswa mengacu pada kontrak matakuliah yang ditetapkan bersama, sehingga mahasiswa memahami alur kegiatan perkulahan baik ketika di kelas atau di luar kelas. Substansi materi perkuliahan dirancang oleh dosen bertujuan untuk mengkonstruksi pemikiran mahasiswa sehingga memunculkan mindset) karakter dan perilaku wirausaha atau entrepreneur.

Nilai-nilai kewirausahaan yang dikembangkan pada materi tersebut diimplementasikan pada kegiatan perkulihan secara interaktif yang diawali dengan: a) kajian teoritik konseptual tentang entrepreneurship dalam rangka menumbuhkan pemahaman yang komprehensih dan terstruktur pada aspek knowledge, b) kegiatan tugas terstruktur dan tugas mandiri di luar tatap muka yaitu memberikan kesempatan kepada mahasiswa untuk menggali pengetahuan dan pengalaman kewirausahaan melalui bahan bacaaan, atau sumber-sumber lain dari media sosial tentang kiat sukses entreprent muda yang menginspirasi, atau c) melakukan mini research yaitu pengamatan kegiatan wirausaha ke tempat tempat bisnis baik lokal skala rumah tangga, kaki lima, dan kegiatan kewirausahaan di lingkungan kampus sebagai bahan pelaporan matakuliah. Nova Tiara mengaskan bahwa:" ... Lembaga pendidikan tinggi seperti halnya IAIN Madura menentukan struktur kurikulum pembelajaran khususnya matakuliah kewirausahaan yang syarat dengan nilai-nilai entrepreneurship didesain pada struktur peta kurikulum institusi yaitu " jarring dan jenjang pada semester pembelajaran pembelajaran kewirausahaan", pada semester empat (4) atau semester enam (6) ...

Pembelajaran kewirausahaan berorientasi pada upaya pembentukan diri mahasiswa jati diri seorang wirausahawan yang bertumpu pada tiga hal yaitu: 1) managerial skill, 2) production technical skill, 3) personality developmental skill, nampak bahwa ketiga aspek ini menjadi merupakan seperangkat kisi-kisi seorang entrepreneur, menuntut pendidikan tinggi melakukan reformulasi pembelajaran sesuai dengan silabus yang disusun dan penekannya pada pilihan aspek tertentu seperti penguatan personality developmental skill disebabkan oleh karaktertik pendidikan tinggi yang menaungi tidak sampai mengenalkan pada kedua aspek sbelumnya.

Managerial skill dan productional skill bukan berarti tidak penting, akan tetapi dalam dilakukan oleh mahasiswa atas bimbingan dosen untuk studi mandiri di lapangan ketika diberikan penugasan di luar kelas, sehingga kedua aspek tersebut dapat diperoleh secara bersamaan, kedua aspek terssbut sangat memungkinkan memberikan pengaaman berharga kepada mahasiswa ketika mengikuti pembelajaran kewiraushaan mereka memperoleh pengalaman tentang skill membuka usaha baru dan belajar belajar bekerja untuk dirinya sendiri. Meskipun demikian penting bahwa ketiga hal tersebut hakekatnya adalah menanamkan sikap dan semangat mandiri serta kemampuan kerjasama dan tertanamnya paradigma wirausaha. ${ }^{8}$

Minat wirausaha mahasiswa dapat ditelaah menggunakan teori motivasi, bahwa ssalah satu diantara aspek psikologis individu tergerak untuk melakukan sesuatu jika mereka mampu beraktualisasi diri di tengah komunitas lingkungan sekitarnya yang

\footnotetext{
Ramdhani dan Nurnida, "Pengaruh Mata Kuliah Kewirausahaan Terhadap Minat berwiarausaha Mahasiswa," 91.

8 Eman Suherman, Desain Pembelajaran Kewirausahaan (Bandung: Alfabeta, 2010), 22-23.
} 
dapat mendorong untuk melakukan usaha mandiri mulai dari yang paling sederhana sampai pada hal hal yang membutuhkan skill managerial dan productional.

Realita yang terjadi di lapangan saat ini, mahasiswa pada jurusan EBIS mengikuti perkuliahan mata kuliah kewirausahaan karena memang hal itu menjadi sebuah keharusan yang harus di tempuh oleh semua mahasiswa. Dengan adanya mata kuliah kewirausahaan ini, mahasiswa dibekali untuk memiliki pemahaman tentang teori kewirausahaan. Tidak hanya itu, mahasiswa juga dibekali untuk memiliki jiwa entrepreneur sehingga dengan adanya mata kuliah kewirausahaan, mahasiswa dapat memiliki peluang kerja bahkan mampu menciptakan sebuah lapangan pekerjaan. Mahasiswa diharapkan agar mampu merealisasikan terhadap teori yang di dapat melalui bangku kuliah menjadi sebuah aksi nyata yang dapat dibangun oleh mahasiswa melalui mata kuliah kewirausahaan. Sehingga peneliti berkeinginan untuk melakukan penelitian dengan judul "Pengelolaan perkuliahan mata kuliah kewirausahaan dalam meningkatkan minat berwirausaha mahasiswa EBIS IAIN Madura."

Diskripsi fenomena kegiatan perkuliahan kewirausahaan di lingkungan PTKIN khususnya Fakultas Ekonomi Bisnis Islam IAIN Madura, mengarah kepada beberapa hal sebagai berikut; pertama, Bagaimana dosen merancang perkuliahan pada mata kuliah kewirausahaan dalam meningkatkan minat berwirausaha pada Mahasiswa Ebis IAIN Madura; kedua, Bagaimana dosen melaksanakan program perkuliahan mata kuliah kewirausahaan dalam meningkatkan minat berwirausaha pada Mahasiswa Ebis IAIN Madura. Ketiga, Bagaimana hasil program perkuliahan mata kuliah kewirausahaan dalam meningkatkan minat berwirausaha pada mahasiswa EBIS IAIN Madura

\section{METODE PENELITIAN}

Ancangan penelitian tentang pengelolaan matakuliah kewirausahaan dalam meningkatkan minat wirausaha mahasiswa, yaitu menggunakan ancangan kualitatif diskriptif, sebab data kualitatif yang diinginkan dalam bentuk kata dan perilaku individu yaitu mahasiswa dalam mengikuti kegiatan perkuliahan, atau pun dalam bentuk artefak gambar dan tulisan yang dapat dikutip berasal dari naskah wawancara, catatan lapangan, foto, catatan atau memo. ${ }^{9}$

Penelitian ini berusaha mengungkap fenomena atau peristiwa sosial yang terjadi dalam pelaksanaan perkuliahan mata kuliah kewirausahaan, yang memungkinkan peneliti hadir di tengah di tengah kegiatan belajar mahasiswa, mengikuti secara non partisipan sehingga mengetahui secara utuk kegiatan persiapan dosen mempersiapkan materi kewirausahaan dan mengebangkan nilai-nilai karakter dalam isi pembelajaran, dan peneliti mengatmati dengan peka terhadap proses pembelajaran yang dilakukan bersama mahasiswa, sehingga nampak interaksi pembelajaran yang dilakukan mampu menumbuhkan minat belajar mahasiswa dapat diketaui dengan seksama dan obyektif..

Peneliti adalah outsider sebagai instrument kunci dapat dengan leluasa menentukan key informan khususnya dosen dan mahasiswa dalam merancang pembelajaran, melaksanakan kajian dan praktik kewirausahaan di kelas atau di luar kelas, bahwa secara procedural penggalian data, melalui pola pengamatan secara non partisipan dapat memperoleh data yang sangat obyektif. Sebab tidak ditemukan human interest . Data hasil pengamatan baik dokumen atau perilaku dosen dan mahasiswa,

$9 \quad$ Lexy J. Moleong, Metodologi Penelitian Kualitatif (Bandung: Remaja Rosdakarya, 2014), 11. 
selanjutnya didalami melalui wawancara mendalam baik terstruktur atau tidak terstruktur, sehingga mampu mengungkap alasan tentang motivasi kewirausahaan yang berujung pada perilaku usaha rintisan mahasiswa dalam menekuni wirausaha setelah mengikuti perkuliahan tersebut.

Data lapangan yang diperoleh baik berupa data primer berupa kata, dokumen, dan perilaku dosen dalam pembelajaran serta mahasiswa yang berusaha memahami konsep wirausaha tersebut, atau pun data skuneder tentang materi yang dikemas dalam kurikulum pembelajaran, selanjutnya diolah melalui tahapan verifikasi yaitu dilakukan pengecekan data yang benar-benar menunjukkan aktifitas pembelajaran di kelas maupun di luar kelas, kemudian dilakukan klasifikasi berdasarkan tema-tema penelitian pada fokus penelitian, sehingga mempermudah dalam membahas dan membuat kesimpulan yang berkitan dengan pengelolaan perkuliahan matakuliah ewirusahaan, dan minat wirausaha yang muncul pada setiap mahasiswa khususnya di Fakultas Ekonomi Bisnis Islam IAIN Madura.

\section{HASIL DAN PEMBAHASAN}

\section{Merancang perkuliahan mata kuliah kewirausahaan dalam meningkatkan minat berwirausaha mahasiswa Ebis IAIN Madura}

Dosen pengampu matakuliah sebagaimana yang dikemukakan oleh (Miss X) berdasarkan surat tugas dari Rektor IAIN Madura, di dalamnya terkandung beban, kewenangan, dan otoritas untuk menyelenggarakan kegiatan pembelajaran bersama mahasiswa, yaitu Matakuliah Kewirausahaan dalam rumpun Kompetensi Dasar (MKD) atau matakuliah umum di tingkat institus, yaitu identitas yang berimplikasi pada pembebanan kurikulum setiap program studi untuk dirancang dan diprogramkan oleh setiap mahasiswa.

Dokumen kurikulum Fakultas Ekonomi Bisnis Islam pada tingkatan institusi IAIN Madura termuat mata kuliah kewirausahaan dengan kode MKD 119 sebesar 2 SKS, bahwa setiap matakuliah memiliki karaktersitik sesuai dengan rumpun jenjangnya yaitu terbebankan untuk mencapai keberhasilan belajar mahasiswa khususnya aspek nilai-nilai kewirausahaan pada unsur Sikap dan tata Nilai yang berbunyi yaitu:"... a) Menginternalisasi semangat kemandirian, kejuangan dan kewirausahaan ..., sedangkan pada unsur keterampilan atau kemampuan kerja berbunyi yaitu b) Memiliki kompetensi kewirausahaan secara teori dan praktek wirausaha ..., ${ }^{10}$ kedua unsur tersebut merupakan Capaian Pembelajaran Program Studi (learning Outcome) yang selanjutnya dikembangkan oleh dosen pengampu matakuliah dalam capaian pembelajaran mata kuliah atau disebut (CPMK), yaiu pada dokumen Rencana Pembelajaran Semesteran disebut (RPS).

Rencana pembelajaran semesteran adalah dokumen kurikulum yang berisi rencana kegiatan tata muka, tugas terstruktur, tugas mandiri dan mini riset yang disusun oleh dosen, Persiapan pembelajaran pertama: dimulai dari dari dirinya sebagai pengajar seperti mempersiapkan referensi dan teori-teori yang berkenaan dengan kewirausahaan, dan yang kedua, mempersiapkan mental mahasiswa untuk mengikuti proses pembelajaran yang efektif dan efisien, bahwa: “...perencanaan merupakan cara untuk menentukan tujuan yang hendak dicapai selama suatu masa

10 Tim Penyusun Kurikulum IAIN Madura, Dokumen Kurikulum Program Studi pada Fakultas Ekonomi Bisnis Islam IAIN Madura (Pamekasan: IAIN Madura, 2017), 11. 
yang akan datang dan apa yang selama suatu masa yang akan datang dan apa yang harus diperbuat agar dapat mencapai tujuan-tujuan tersebut, ,", ${ }^{11}$ tujuan tersebut termaktub pada CPMK baik pengetahuan dan kemampuan kerja berwirausaha mandiri.

Perencanaan pembelajaran yang dilakukan oleh dosen hakekatnya adalah upaya: “... melakukan proses yang berkesinambungan, mencakup keputusan atau pilihan berbagai alternatif penggunaan sumberdaya untuk mencapai tujuan tertentu yang telah ditetapkan ${ }^{12}$, bahwa persiapan pembelajaran yang akan dimulai dimulai oleh Dosen, mereka menetapkan pilihan strategi pembelajaran dan atau metode/teknik yang mampu mendorong mahasiswa tidak hanya mendengarkan terusmenerus penjelasan dosen di kelas, melainkan ikut aktif terlibat belajar secara totalitas, mental mahasiswa dipersiapkan agar tidak hanya sekedar belajar pengetahuan konseptual belaka, akan tetapi diarahkan untuk melihat secara langsung praktek kewirausahaan di tengah komunitas kampus dan di luar kampus.

Penetapan strategi pembelajaran yang partisipatoris seperti diskusi dan praktek kewirausahaan di lingkungan sekitar kampus, dan di luar kampus seperti pengamatan langsung ke komunitas wirausaha di masyarakat, khususnya bagi mahasiswa Ekonomis Bisnis Islam IAIN Madura yaitu diharapkan agar mahasiswa mempu memahami, cakap, terampil dalam berwirausaha. Orientasi utama pembelajaran kewirausahaan bagi mahasiswa adalah upaya untuk membentuk mental wirausaha dan membangun minat wirausaha. Pembentukan mental dan minat wirausaha dalam rancangan pembelajaran yang dikemas oleh dosen dalam bentuk RPS mencakup pada empat (4) hal utama yaitu: a) capaian pembelajaran matakuliah atau disebut komptensi lulusan yaitu cakap pengetahuan kewirausahaan, dan mental serta minat berwirausaha, b) isi matakuliah atau bahan kajian yang memuat teori, praktek dan attitude kewirausahaan melalui referensi dan teori-teori yang berkenaan dengan kewirausahaan dan juga mental mahasiswa, c) strategi pembelajaran kooperatif partisipatoris baik di kelas atau di luar kelas. yaitu memanfaatkan teknik atau metode yang menyenangkan dalam pembelajaran kewirausahaan, d) penilaian pembelajaran mata kuliah kewirausahaan yaitu lebih diarahkan pada tugas-tugas, dan praktek kewirausahaan yang telah dilakukan selama proses perkuliahan dalam bentuk laporan penugasan hasil pengamatan lapangan.

Perencanaan pembelajaran matakuliah kewirausahaan pada Fakultas Ekonomi Bisnis Islam IAIN Madura yang dilakukan oleh setiap Dosen yaitu merancang hasil atau tujuan akhir yang termaktub pada masing-masing pertemuan tatap muka atau non tatap muka sebagai penjabaran capaian pembelajaran matakuliah. Tujuan tersebut merupakan performance yaitu hasil akhir terbangunnya jiwa atau karakter nilai-nilai kewirausahaan yang melekat pada setiap mahasiswa, bahwa mahasiswa merasakan pengalaman belajar yang dapat membawa dirinya memiliki minat berwirausaha, dan mampu mengaktualisir dalam menjadi calon wirausahan yang inovatif dan kreatif. ${ }^{13}$

1 George R. Terry dan Leslie W. Rue, Dasar-Dasar Manajemen (Jakarta: Bumi Aksara, 2016), 10.

Rusdiana, Kewirausahaan Teori dan Praktik (Bandung: CV. Pustaka Setia, 2018), 181.

Suherman, Desain Pembelajaran Kewirausahaan, 20-21. 


\section{Pelaksanaan perkuliahan mata kuliah kewirausahaan dalam meningkatkan minat berwirausaha mahasiswa Ebis IAIN Madura}

Pelaksanaan perkuliahan mata kuliah kewirausahaan dalam meningkatkan minat berwirausaha mahasiswa, sesuai dengan kontrak pembelajaran yang dilakukan oleh dosen bersama mahasiswa yaitu mengaktualisikan strategi pembelajaran yang ditetapkan berdasarakan karakteristik materi atau bahan kajian yang ada pada RPS yang telah disusun sebelumnya, seperti bahan:"... tentang konsep dasar kewirausahaan dan sikap pribadi wirausaha ...", ${ }^{14}$ mahasiswa dan dosen terlibat aktif melakukan diskusi. Dosen menyampaikan pokok pokok pikiran atau konsep tentang kewirausahaan, dan ciri-ciri seorang wirausahawan, maka kegiatan selanjutnya dilakukan Tanya jawab kemudian mendiskusikan materi tersebut bersama mahasiswa.

Materi tentang ciri dan karakter seorang wirausahaan dikaji dalam kelas, bahwa dosen bersama mahasiswa yaitu dilakukan dengan memberikan tugas untuk menggali literature-literatur bacaan di perpustakaan atau sumber lain yang mudah yaitu on line journal dan dibawa ke kelas sebagai bahan diskusi. Kegiatan pembelajaran kewirausahaan melalui diskusi dan pembahasan yang komprehensif inilah sangat memudahkan pada mahasiswa untuk mengurai, memaparkan dan mengambil kesimpulan yang dapat digunakan untuk membangun kerangka pikir mahasiswa terhadap materi sikap pribadi wirausaha, pilihan strategi pembelajaran yang tepat akan mendorong kepada mahasiswa mencapai tujuan pembelajarannya, bahwa:"... metode pembelajaran yang dapat menumbuhkan minat wirausaha, kemampuan guru/ dosen dalam kelas atau di lingkungan kelas dituntut mampu menumbuhkan minat wirausaha, serta pengalaman langsung yang dapat menumbuhkan minat berwiarausaha....." ${ }^{15}$

Prinsip dasar dalm pelaksanan perkuliahan yang berkaitan dengan kegiatan inti pembelajaran, dosen mengimplementasikan pelaksanaan metode pembelajaran sesuai dengan silabus atau RPS yang telah ditetapkan sehingga tidak melenceng dari garisgaris besar program pembelajaran, namun dosen diberi kesempatan untuk berimprovisasi dalam kegiatan pembelajaran tersebut menggunakan metode yang bervariasi untuk meningkatkan perhatian mahasiswa. ${ }^{16}$

Kedudukan metode adalah sebagai alat motivasi eksterinsik, sebagai strategi pengajaran dan juga sebagai alat untuk mencapai tujuan. Penggunaan metode dalam suatu pembelajaran kewirausahaan salah satu cara untuk mencapai sebuah keberhasilan dalam pembelajaran. Semakin pandai seorang pengajar menentukan metode yang akan digunakan dalam pembelajaran, maka keberhasilan yang diperoleh dalam mengajar semakin besar pula. Pilihan metode pembelajaran yang tepat tersebut maka dosen bersama mahasiswa sangat memungkinkan saling berkontribusi aktif untuk membangun dirinya memahami katrakter kewirausahaan dan juga

14 Madura, Dokumen Kurikulum Program Studi pada Fakultas Ekonomi Bisnis Islam IAIN Madura.

15 Christianingrum dan Erita Rosalina, "pengaruh Pembelajaran Kewirausahaan Terhadap Minat Berwirausah," Integrated Journal of Business and Economies (IJBE) 1, no. 1 (2017): 49.

16 Lutfi, "Pengelolaan Pembelajaran Kewirausahaan di Universitas Negeri Padang," Jurnal Administrasi Pendidikan Fakultas Ilmu Pendidikan Universitas Negeri Padang 1 (2016): 5. 
membangun ide kreatif rencana wirausaha dalam proses pembelajaran yang berlangsung. ${ }^{17}$

Pola pembelajaran matakuliah kewirausahaan diperkuat dengan adanya praktek kewirausahaan, tujuan kegiatan praktek tersebut dilakukan untuk menggali potensi mahasiswa, untuk menggali ide-ide kreatif dan inovatif mahasiswa dan keterampilan mahasiswa. Praktek yang dilakukan disini mahasiswa berjualan dengan hasil ide-ide kreatif dari mereka. Memang pembelajaran kewirausahaan di lingkungan Pendidikan Tinggi Keagamaan masih belum mampu menjangkau yang lebih jauh seperti halnya di Univeritas Man Chung bahwa: “...satu angkatan yang mengikuti kuliah kewirausahaan sebanyak 130-200 orang. Dari jumlah ini, 10-20 persen benar-benar memiliki usaha. Bahkan usaha itu dimiliki saat kuliah. Dosen terjun langsung membina dan ikut menyumbang ide usaha, menyeleksi yang terbaik, mengawasi dan turun lapangan, melihat, hingga memastikan usaha mahasiswa tersebut untung. ${ }^{18}$

Capaian pembelajaran program studi pada Fakultas EBIS IAIN Madura menyebutkan bahwa mahasiswa dituntut mampu menginternalisir kemandirian diri, semangat kejuangan, dan kewirausahaan, yang dapat digunakan untuk menyelesaikan masalah dirinya dalam kehidupan sehari-hari terkait upayaa memenuhi kebutuhan hidupnya. Suatu capaian pembelajaran yang tidak mudah untuk dicapai hanya dengan 2 SKS, pada beban matakuliah kewirausahaan. Oleh karenanya dosen dituntut untuk memiliki kemampuan kreatif dalam melakukan proses pembelajaran selama enam belas (16) kali tatap muka di kelas atau praktek lapangan di luar kelas sehingga pembelajaran kewirausahaan diharapkan dapat:"...mempengaruhi minat berwirausaha. Minat seseorang terhadap suatu obyek diawali dari perhatian seseorang terhadap obyek tersebut. Minat merupakan suatu hal yang sangat menentukan dalam setiap usaha, maka minat perlu ditumbuhkembangkan pada diri setiap entrepreneur. ${ }^{19}$

\section{Hasil pengelolaan perkuliahan mata kuliah kewirausahaan dalam meningkatkan minat berwirausaha mahasiswa Ebis IAIN Madura}

Tingkat keberhasilan perkuliahan mata kuliah kewirausahaan dalam meningkatkan minat berwirausaha mahasiswa Ebis IAIN Madura ini di lihat dari kreatifitas mahasiswa. Mata kuliah kewirausahaan dikatakan berhasil ketika mahasiswa sudah mampu mengeluarkan ide-ide kreatif dan inovatifnya. Jadi nilai kreatif yang dipentingkan dosen dalam mengukur tingkat keberhasilan mahasiswa. Kemudian dosen juga melihat beberapa (tidak semuanya) mahasiswa yang mempunyai usaha sendiri.

Pembelajaran kewirausahaan tidak hanya mengajarkan mahasiswa untuk memperoleh uang/memanfaatkan peluang sebesar-besarnya, melainkan cara-cara untuk mendapatkan keuntungan untuk mendapatkan keuntungan tersebut, haruslah dilakukan dengan cara yang benar. Dalam kaitannya dengan penilaian, dosen

17 Ramdhani dan Nurnida, "Pengaruh Mata Kuliah Kewirausahaan Terhadap Minat berwiarausaha Mahasiswa," 92.

18 M. Kubais dan M. Zeen, Menggerakkan Jiwa Entrepreneur (Yogyakarta: Gosyen Publishing, 2018), 48-49.

19 Aidha, "Pengaruh motivasi Terhadap Minat Berwirausaha Mahasiswa Fakultas Kesehatan Masyarakat Universitas Islam Negeri Sumatera Utara," 46. 
meberikan penilaian tidak hanya dari segi pengetahuan saja, tetapi juga dari segi keahlian dan sikap mahasiswa. ${ }^{20}$

Kreatifitas menurut Julius Chandra ialah kemampuan mental dan berbagai jenis keterampilan khas manusia yang dapat melahirkan pengungkapan yang unik, berbeda, orisinal, sama sekali baru, indah, efisien, tepat sasaran dan tepat guna. Kemudian H. Herbert Fox mengemukakan suatu proses kreatif yaitu setiap proses berpikir yang dapat memcahkan persoalan tertentu dengan cara orisinal dan bermanfaat. Dikemukakan pula Harold Koontz dan Heinz Weihrich istilah kreatifitas biasanya berhubungan dengan kemampuan dan kekuatan untuk mengembangkan ideide baru. Sebetulnya masih banyak keterangan para ahli mengenai kreatifitas ini. Namiun dari penjelasan beberapa para ahli tadi saja nampaknya sudah dapat di sarikan bahwa kreatifitas sangat berkaitan dengan kemampuan seorang untuk memikirkan dan membuat sesuatu yang relatif orisinal dan bermanfaat bagi khalayak. $^{21}$

Menurut para ahli, keberhasilan pendidikan tergantung 3 komponen utama yakni mahasiswa, dosen atau pendidik, dan manajemen lembaga pendidikan yang bersangkutan, meskipun dosen atau pendidik memiliki peran sentral, namun perlu ditopang oleh perangkat pembelajaran terkait lainnya secara sistemik. Dengan dimikian, hendaknya ada satu sistem yang dijadikan pedoman oleh semua unsur pembelajaran agar bila ada persoalan bukan aspek personal yang menjadi acuan dalam mencari solusi, melainkan aspek manajerial yang dijadikan pola untuk mengatasi dan menyelesaikan setiap masalah yang terjadi. Jika demikian, tujuan pembelajaran kewirausahaan akan tercapai.

Adapun indikasi penting tercapainya tujuan pembelajaran kewirausahaan ialah tumbuhya jiwa wirausaha dalam pribadi peserta didik, yang imbasnya diharapkan dapat meningkatkan kualitas kegiatan perekonomian negeri merdeka ini, mengurangi kemiskinan dan menanggulangi masalah pengangguran yang kian hari makin bertambah. ${ }^{22}$ Hasil pembelajaran matakuliah kewirausahaan tidak hanya sebatas mampu menciptakan seseorang untuk mampu menciptakan kegiatan usaha, tetapi yang terpenting lebih ditumbuhkan adalah:"...bahwa dalam berwirausaha ada beberapa hal yang perlu menjadi modal selain materi modal yang bersifat non materi perlu dimiliki seseorang yang mau memilih untuk berwirausaha. Salah satu modal selain materi yang harus dimiliki untuk berwirausaha adalah minat berwirausaha. ${ }^{23}$

Hasil kegiatan pembelajaran kewirausahaan yang dilakukan dalam kegiatan perkuiahan secara terstruktur sistematis, melalui pengelolaan kurikulum pendidikan tinggi, maka atas dasar tujuan dan pengertian kewirausahaan yang terperinci dan luas, akan mengarahkan sasaran kewirausahaan yang luas pula yang meliputi orang, kelompok orang dan kelompok usaha. Secara lengkap sasaran kewirausahaan seperti disarikan oleh Alma yaitu menghasilkan individu atau mahasiswa sebagai: a) Wanita Pengusaha, b) Minoritas Pengusaha, c) Imigrasi Wirausaha, d) Wirausaha Paruh

20 Lutfi, "Pengelolaan Pembelajaran Kewirausahaan di Universitas Negeri Padang," 6.

21 Suherman, Desain Pembelajaran Kewirausahaan, 21.

22 Suherman, 26.

23 Reza Fahmi dan Tri Amanda, "Pengaruh Pembelajaran Kewirausahaan Terhadap Minat Berwirausaha Mahasiswa," Jurnal Ekonomi dan Bisnis Islam 2, no. 1 (2017): 36. 
Waktu, e) Pengusaha Rumah Tangga, f) Wirausaha Keluarga, g) Wirausaha Pemula. $^{24}$

\section{KESIMPULAN}

Berdasarkan hasil pembahasan atas hasil penelitian tentang pengelolaan matakuliah kewirausahaan dalam upaya membentuk minat wirasauaha mahasiswa Fakultas EBIS IAIN Madura dapat disimpulkan: (a) Dalam merancang perkuliahan mata kuliah kewirausahaan dalam meningkatkan minat berwirausaha mahasiswa diperlukan persiapan dengan matang dan mempersiapkan segala sesuatunya dengan baik sebelum masuk dalam kelas dan pembentukan mental mahasiswa agar mahasiswa tidak hanya mendengarkan dalam kelas namun juga aktif dalam perkuliahan dan tidak merasa bosan atau jenuh pada saat didalam kelas. Hal itu sudah dilakukan dengan sebaik mungkin pada Fakultas Ebis IAIN Madura. (b) Pelaksanaan merupakan realisasi atau tindak lanjut dari adanya perencanaan yang ditetapkan sebelumnya. Pelaksanaan yang dilakukan di Fakultas Ebis IAIN Madura sudah dilakukan sesuai dengan rancangan kegiatan program perkuliahan mata kuliah kewirausahaan yaitu melalui adanya kegiatan diskusi dan praktek. Diskusi disini dilakukan dengan metode ceramah yang dilakukan dosen, dimana dosen mengajarkan mahasiswa teori-teori yang berkenaan dengan kewirausahaan. Pemberian motivasi dan semangat juga dilakukan dalam pelaksanaan perkuliahan mata kuliah kewirausahaan untuk menggali kreatifitas dan inovasi mahasiswa. (c) Tingkat keberhasilan mata kuliah kewirausahaan dalam meningkatkan minat berwirausaha mahasiswa Ebis IAIN Madura diukur dengan cara apabila mahasiswa memahami, mandiri, mengeluarkan ide-ide kreatifnya dan mempunyai semangat kewirausahaan yang besar. Mata kuliah kewirausahaan Fakultas Ebis IAIN Madura dikatakan sukses apabila mahasiswa tidak merasa tertekan kemudian mereka bisa dengan leluasa dalam mengeluarkan ide tanpa takut-takut. Jadi nilai kreatif lah yang menjadi point penting, ketika mahasiswa yang pertamanya diam kemudian setelah mempelajari ilmu kewirausahaan mereka sudah mulai kreatif dan bisa mengeluarkan ide-ide kreatifnya maka disitulah kewirausahaan sudah mulai masuk.

Berdasarkan hasil penelitian yang telah dipaparkan di atas, maka selanjutnya peneliti menyampaikan saran-saran yang kiranya dapat bermanfaat bagi pihak-pihak yang terkait atas hasil penelitian ini. Adapun saran-saran tersebut yaitu sebagai berikut: (a) Bagi pihak Fakultas Ebis IAIN Madura, Penelitian ini diharapkan dapat meningkatkan kinerja dosen dalam meningkatkan minat berwirausaha mahasiswa agar mahasiswa dapat lebih tertarik dan minat dalam berwirausaha. (b) Bagi peniliti selanjutnya diharapkan untuk dikembangkan lagi dengan cara mencari subjek yang berbeda dengan objek yang sama, misalnya dengan melakukan penelitian lebih mendalam terkait dengan manajemen kewirausahaan. Sehingga dapat memperluas pengetahuan mahasiswa. Sehingga dapat menjadi bahan koreksi dari kekurangan ataupun refrensi yang bisa menjadi rujukan unuk penelitian selanjutnya. (c) Bagi lembaga IAIN MADURA, hasil penelitian ini diharapkan bisa dijadikan referensi untuk melakukan penelitian selaanjutnya. Sehingga bisa dikembangkan dan tidak berakhir

24 Mustofa Kamil, Model Pendidikan dan Pelatihan; Konsep dan Aplikasi, ed. oleh M.Pd. Dr. Riduwan, M.B.A., Kesatu (Bandung: Alfabeta, 2012), 56. 
hanya dipenelitian ini saja. Dengan demikian, bisa menemukan teori-teori baru yang relevan dengan penelitian ini.

\section{DAFTAR PUSTAKA}

Ahmad Subagyo, Eko Wahyu Widayat, dan Syahruddin. Kewirausahaan. Jakarta: Mitra Wacana Media, 2018.

Aidha, Zuhrina. "Pengaruh motivasi Terhadap Minat Berwirausaha Mahasiswa Fakultas Kesehatan Masyarakat Universitas Islam Negeri Sumatera Utara." Jurnal Jumantik 1, no. 1 (2016).

Aini, Yulfita. "Pengaruh Pembelajaran Kewirausahaan Terhadap Minat Mahasiswa Upp Berwirausaha". Jurnal Ilmiah Cano Ekonomos. Volume 3. Number 1. Januari, 2015.

Arikunto, Suharsimi. Manajemen Penelitian. Jakarta: Rineka Cipta, 2013.

Aziz, Abdul. Pengantar Manajemen dan Substansi Administrasi Pendidikan. Surabaya: Pena Salsabila, 2017.

Buchari, Alma. Pengantar Bisnis. Bandung: Alfabeta, 2010.

Buna'i. Penelitian Kualitatif. Pamekasan: Stain Pamekasan Press, 2008.

Christianingrum, dan Erita Rosalina. "pengaruh Pembelajaran Kewirausahaan Terhadap Minat Berwirausah." Integrated Journal of Business and Economies (IJBE) 1, no. 1 (2017).

Fahmi, Reza, dan Tri Amanda. "Pengaruh Pembelajaran Kewirausahaan Terhadap Minat Berwirausaha Mahasiswa." Jurnal Ekonomi dan Bisnis Islam 2, no. 1 (2017).

Febrianto. "Strategi Peningkatan Kewirausahaan Bagi Mahasiswa di Perguruan Tinggi". Jurnal Bisnis Darmajaya. Volume 1. Number 1. Januari, 2015.

Gunawan, Imam. Metode Penelitian Kualitatif. Jakarta: Bumi Aksara, 2014.

Hariani, Cicik dan Yulianeu, "Analisis Faktor-Faktor yang Memperngaruhi Minat Berwirausaha pada Remaja Karang Taruna Wijaya Kusuma Kelurahan Kramas Kecamatan Tembalang Kota Semarang”. Jurnal Disprotek. Volume 9. Number 1. Januari, 2016.

Kamil, Mustofa. Model Pendidikan dan Pelatihan; Konsep dan Aplikasi. Diedit oleh M.Pd. Dr. Riduwan, M.B.A. Kesatu. Bandung: Alfabeta, 2012.

Kubais, M., dan M. Zeen. Menggerakkan Jiwa Entrepreneur. Yogyakarta: Gosyen Publishing, 2018.

Lutfi. "Pengelolaan Pembelajaran Kewirausahaan di Universitas Negeri Padang." Jurnal Administrasi Pendidikan Fakultas Ilmu Pendidikan Universitas Negeri Padang 1 (2016).

Madura, Tim Penyusun Kurikulum IAIN. Dokumen Kurikulum Program Studi pada Fakultas Ekonomi Bisnis Islam IAIN Madura. Pamekasan: IAIN Madura, 2017.

Moleong, Lexy J. Metodologi Penelitian Kualitatif. Bandung: Remaja Rosdakarya, 2014.

Mulyasa, H.E. Manajemen dan Kepemimpinan Kepala Sekolah. Jakarta: Bumi Aksara, 2017.

Rahmadi, Alif Nur. "Analisis Faktor-Faktor yang Mempengaruhi Minat Berwirausaha pada Mahasiswa Program Studi Manajemen Fakultas Ekonomi Universitas 
Kediri”. Jurnal Ekonomi Universitas Kediri. Volume 1. Number 2. September, 2016.

Rahmawati. Bisnis Usaha Kecil Menengah; Akuntansi, Kewirausahaan, dan Manajemen Pemasaran. Yogyakarta: Ekuilibria, 2016.

Ramdhani, Nova Tiara, dan Ida Nurnida. "Pengaruh Mata Kuliah Kewirausahaan Terhadap Minat berwiarausaha Mahasiswa." Jurnal Ecodomica 1, no. 1 (2017).

Rusdiana. Kewirausahaan Teori dan Praktik. Bandung: CV. Pustaka Setia, 2018.

Rosmiati dan Teguh Santosa Junias, Donny dan Munawar. "Sikap, Motivasi, dan Minat Berwirausaha Mahasiswa". Jurnal Manajemen dan Kewirausahaan. Volume 17. Number 1. Maret, 2015.

Subanar, Harimurti. Manajemen Usaha Kecil. Yogyakarta: BPFE, 2009.

Sugiyono. Metodelogi Penelitian Kualitatif dan R\&d. Bandung: Alfabeta, 2010.

Suharsaputra, Uhar. Metode Penelitian. Bandung: Refika Aditama, 2012.

Suherman, Eman. Desain Pembelajaran Kewirausahaan. Bandung: Alfabeta, 2010.

Terry, George R., dan Leslie W. Rue. Dasar-Dasar Manajemen. Jakarta: Bumi Aksara, 2016.

Widnyana, I Wayan, Sapta Rini Widyawati, dan G. Oka Warmana. "Pengaruh Pemberian Mata Kuliah Kewirausahaan dan Pelatihan Wirausaha Terhadap Minat Wirausaha Ekonomi Kreatif." Jurnal Bakti Masyarakat Indonesia 1, no. 1 (2018).

Wijaya, David. Pendidilkan Kewirausahaan. Yogyakarta: November, 2017. 